\title{
Bleeding Diathesis Due to Decreased Functional Activity of Type 1 Plasminogen Activator Inhibitor
}

Raymond R. Schleef," Deborah L. Higgins," Eric Pillemer, and Lee J. Levitt

Department of Medicine, Stanford University Medical Center, Stanford, California 94305; * Department of Immunology, Research Institute of Scripps Clinic, La Jolla, California 92037; ' Department of Cardiovascular Research, Genentech, Inc., South San Francisco, California 94080

\begin{abstract}
We evaluated an elderly patient with a lifelong history of severe bleeding after surgery or trauma and with evidence of persistent hyperfibrinolysis. Routine coagulation studies were normal. Serum plasminogen (40\%, normal $72-128 \%)$ and $\alpha_{2}-$ antiplasmin (55\%, normal 70-145\%) activities were decreased. Euglobulin clot lysis was abnormally shortened $(50 \mathrm{~min})$ and normalized in vitro with $\epsilon$-aminocaproic acid (EACA). The patient was treated with EACA with prompt cessation of bleeding. Patient tissue-plasminogen activator (t-PA) levels in serum were normal $(4.7 \mathrm{ng} / \mathrm{ml}$, control $3.5-7.2)$ as detected by a two-site immunoradiometric assay (IRMA). Patient fibrinolytic inhibitor activities were assessed by incubating ${ }^{125} \mathrm{I}$-labeled t-PA with either whole blood or serum followed by SDSPAGE and autoradiography to identify the resultant protease/ protease inhibitor complexes. In comparison to blood samples obtained from normal donors, patient plasma and serum demonstrated reduced binding of a fast-acting plasminogen activator inhibitor to ${ }^{125}$ I-labeled t-PA. Immunoprecipitation experiments indicated diminished complex formation between type 1 plasminogen activator inhibitor (PAI-1) in patient serum and ${ }^{125}$ I-labeled t-PA. Low patient PAI-1 activity was confirmed in serum $(0.36 \mathrm{U} / \mathrm{ml}$, control $0.87-1.81 ; n=3)$ and in platelet lysates using a functional IRMA to quantitate PAI-1 binding to immobilized t-PA. However, patient serum PAI-1 antigen was within the normal range when analyzed by IRMA $(31.8 \mathrm{ng} / \mathrm{ml}$, control 19.6-42.2); this result was confirmed in both serum and platelets by Western blot $(n=3)$. Mixing experiments using purified PAI-1 as well as patient and control sera did not show evidence for an inhibitor against PAI-1. We conclude that this patient's bleeding diathesis was due to hyperfibrinolysis and defective PAI-1. This patient provides the first demonstration of a link between decreased in vivo PAI-1 activity and disordered hemostasis, and supports a role for PAI-1 in control of in vivo fibrinolysis.
\end{abstract}

\section{Introduction}

Regulation of fibrinolysis is critical during hemostasis, wound repair, neoplasia, inflammation, and other biologic processes (1-3). Proteolytic degradation of fibrin clots is mediated by the

This work was presented in part at the annual meeting of the American Society of Hematology, Washington, DC, December 1987, and has been published in abstract form (1987. Blood. 70:378a).

Address reprint requests to Dr. Levitt, Room S-161, Hematology Division, Stanford, CA 94305-5112.

Received for publication 27 June 1988 and in revised form 28 October 1988.

\section{J. Clin. Invest.}

(c) The American Society for Clinical Investigation, Inc. 0021-9738/89/05/1747/06 $\$ 2.00$

Volume 83, May 1989, 1747-1752 enzyme plasmin. Plasmin is formed in the circulation from the zymogen plasminogen through the proteolytic action of plasminogen activators (PAs). ${ }^{1}$ PAs are highly specific serine proteases found in normal or neoplastic tissues and can be divided into two distinct groups, tissue-type (t-PA) and urokinase-type (u-PA) plasminogen activator (4). The principal physiologic inhibitor of plasmin is $\alpha_{2}$-antiplasmin. Inhibitors of plasminogen activation also appear to play an important role in the physiologic control of fibrinolysis (5). At least four immunologically distinct molecules with plasminogen activator inhibitor (PAI) activity have been identified (6). Type 1 PAI (PAI-1), formerly termed the endothelial cell PA inhibitor, inhibits both t-PA and u-PA by forming 1:1 stoichiometric complexes with them. It has been detected in a large variety of cells cultured in vitro, and is also found in plasma and in the $\alpha$-granules of blood platelets (5-7). A number of experimental observations support the hypothesis that PAI- 1 is the principal physiologic inhibitor of t-PA and a primary regulator of in vivo fibrinolysis (6-8). In this study we report our investigations of an elderly man with a lifelong history of postoperative bleeding who was found to have sustained hyperfibrinolysis. Our results suggest that his bleeding diathesis is due to decreased functional activity of PAI-1.

\section{Methods}

\section{Case report}

The patient is a 76-yr-old man seen in consultation for persistent bleeding after transurethral resection of the prostate. He had a long history of bleeding after surgery. In 1969 severe postoperative bleeding occurred after total hip replacement. In 1978 revision of his hip prosthesis was associated with postoperative bleeding requiring $10 \mathrm{U}$ of packed red blood cells. From 1978 to 1981, five episodes of upper gastrointestinal bleeding occurred requiring multiple blood transfusions. No specific site of bleeding was identified despite upper gastrointestinal series and endoscopy. In 1984, the patient fell on his side and developed a massive hematoma; the prothrombin time (PT), partial thromboplastin time (PTT), and platelet count were all normal. In August 1986, he developed obstructive urinary symptoms and underwent a transurethral resection of the prostate. Pathology revealed benign hyperplasia. The postoperative course was complicated by bleeding requiring $4 \mathrm{U}$ of packed red blood cells. The PT, PTT, platelet count, and bleeding time were all normal. Bleeding resolved but the patient was readmitted $3 \mathrm{~d}$ after discharge with persistent gross hematuria. Cystoscopy was negative and clot was evacuated. The patient continued to bleed and was treated with $8 \mathrm{U}$ of red blood cells and $8 \mathrm{U}$ of fresh-frozen plasma without cessation of bleeding. Consultation was requested. Routine coagulation studies were normal including the PT and PTT. There was no evidence of ongoing disseminated intravascu-

1. Abbreviations used in this paper: EACA, $\epsilon$-aminocaproic acid; IRMA, immunoradiometric assay; PA, plasminogen activator; PAI-1, type 1 plasminogen activator inhibitor; $\mathrm{p}$-APMSF, $p$-amidinophenylmethylsulfonyl fluoride; PT, prothrombin time; PTT, partial thromboplastin time; t-PA, tissue-type plasminogen activator; u-PA, urokinase-type plasminogen activator. 
lar coagulation with normal fibrinogen ( $256 \mathrm{mg} / \mathrm{dl}$, normal 160-350), thrombin and reptilase times and D dimer, and only modestly (20-40, normal $<10$ ) elevated fibrin degradation products. The bleeding time and von Willebrand factor antigen, ristocetin cofactor, and factor VIII coagulant activity were normal, suggesting that a diagnosis of von Willebrand's disease was unlikely. Although routine coagulation tests were normal, there was evidence of ongoing fibrinolysis with a shortened euglobulin clot lysis time ( $50 \mathrm{~min}$, normal no lysis at $2 \mathrm{~h}$ ) which partially corrected in vitro $(1 \mathrm{~h}, 45 \mathrm{~min})$ after the addition of the antifibrinolytic agent, $\epsilon$-aminocaproic acid (EACA). Additionally, serum plasminogen ( $40 \%$, normal $72-128 \%$ ) and $\alpha_{2}$-antiplasmin $(55 \%$, normal $70-145 \%$ ) were persistently decreased. The patient was presumed to have a hyperfibrinolytic state of undetermined etiology and was treated empirically with EACA with prompt resolution of his bleeding. When seen in the clinic over the next 2 wk to 10 months, he continued to have laboratory evidence of hyperfibrinolysis with decreased levels of $\alpha_{2}$-antiplasmin and plasminogen, despite no clinical evidence of bleeding. Plasma urokinase by radioimmunoassay was normal. An intensive search for a primary or metastatic tumor, including numerous radiographic and laboratory tests, was unrevealing. Review and resection of the patient's excised prostate showed no evidence of malignancy. The patient's antithrombin III level in stored serum from his hospital admission was normal $(91 \%$, normal range 86-120\%), thus providing further evidence against disseminated intravascular coagulation; interestingly, his $\alpha_{2}$-antiplasmin (55\%) and plasminogen (68\%) levels continue to be abnormally low 2 yr after his diagnosis of disordered fibrinolysis while his antithrombin III levels continue to remain within the normal range.

Both of the patient's parents were deceased at the time of evaluation and the patient had no siblings. The patient's mother was known to have had unexplained severe hemorrhage after a hysterectomy. The patient has two children; both sons are alive and well and have no history suggestive of a bleeding dyscrasia. However, neither son has undergone any surgical procedure nor experienced severe trauma. Both sons have normal serum levels of plasminogen and $\alpha_{2}$-antiplasmin.

\section{Procedures}

Preparation of plasma, serum, and platelets. Whole-blood serum was prepared by collecting blood into glass tubes, allowing the blood to clot at $37^{\circ} \mathrm{C}$ for $1 \mathrm{~h}$, then removing the clot by centrifugation at $1,800 \mathrm{~g}$ for $20 \mathrm{~min}$ at $4^{\circ} \mathrm{C}$. The resulting serum was collected and stored at $-70^{\circ} \mathrm{C}$ until used. Platelet-poor plasma was prepared by collecting blood in $3.8 \%$ sodium citrate, followed by centrifugation at $1,800 \mathrm{~g}$ for $30 \mathrm{~min}$ at $4^{\circ} \mathrm{C}$. Platelet-rich plasma was obtained by centrifugation of citrated blood at $160 \mathrm{~g}$ for $15 \mathrm{~min}$ at $23^{\circ} \mathrm{C}$. The platelet-rich plasma was then centrifuged at $660 \mathrm{~g}$ for $15 \mathrm{~min}$ at $23^{\circ} \mathrm{C}$ and the platelet pellet resuspended in calcium-free Hepes-Tyrodes buffer, $\mathrm{pH}$ 6.5. Platelets were washed by gel-filtration through Hepes-Tyrodes buffer, $\mathrm{pH} 7.3$, as described (9). Alternatively, the platelet pellet was diluted to $10^{9}$ platelets/ml and lysed by addition of $1.0 \%$ Triton X-100.

Reagents and fibrinolytic proteins. Natural human t-PA was purified from media conditioned by human melanoma cells, according to published protocols (10). Recombinant t-PA was purified from media conditioned by transfected Chinese hamster ovary cells (11). The t-PA International Standard (83/517) was kindly provided by the National Institute for Biological Standards and Controls (London). Goat antiserum to t-PA was obtained from Bio-Pool (Hornefors, Sweden) and the IgG fraction was prepared as described (10). Bovine and human PAI-1 were purified as described from media conditioned by either bovine aortic endothelial cells or by a transformed human lung fibroblast cell line (SV40 WI38 VA13 2RA) (12). PAI-1 was isolated primarily in latent form and activated by treatment for $1 \mathrm{~h}$ at $37^{\circ} \mathrm{C}$ with 4 $\mathrm{M}$ guanidine-hydrochloride followed by dialysis at $4^{\circ} \mathrm{C}$ (12). PAI-1 activity was quantitated by measuring its ability to inhibit t-PA-mediated lysis of ${ }^{125}$ I-labeled fibrin $(13,14)$. One unit of PAI-1 is defined as the amount required to inhibit the activity of 2 IU of t-PA by $50 \%$. Antiserum to purified PAI-1 was raised in New Zealand rabbits and was shown to be monospecific by immunoprecipitation and by two- dimensional gel electrophoresis (15). Monoclonal antibody (MAB 2D2) directed against human PAI-1 was produced according to described protocols (10). Thrombin was a generous gift from Dr. J. Fenton (New York State Department of Health, Albany, NY). Pancreatic elastase was purchased from Elastin Products Co. (Pacific, MO). Molecular mass markers for SDS-PAGE were purchased from Sigma Chemical Co. (St. Louis, MO) and included myosin (205,000 D), $\beta$ galactosidase (116,000 D), BSA (66,000 D), egg albumin (45,000 D), and carbonic anhydrase (29,000 D).

Blood proteinase inhibitor complex assay. This assay was performed to assess the ability of inhibitors in whole blood to form complexes with ${ }^{125}$ I-labeled t-PA ( ${ }^{125}$ I-t-PA) (11). Purified recombinant t-PA was radiolabeled with Enzymobeads (Bio-Rad Laboratories, Richmond, CA) as described (11). Freshly drawn, citrated whole blood $(500 \mu \mathrm{l})$ was incubated with $2 \times 10^{5} \mathrm{cpm}$ of ${ }^{125}$ I-labeled enzyme at $37^{\circ} \mathrm{C}$ for 0-24 h. Plasma samples were then removed and centrifuged to remove cells. Less than $5 \%$ of the label was associated with the cellular fraction. Samples were diluted with $10 \mathrm{vol}$ of $2 \%$ SDS buffer and analyzed by SDS-PAGE ( $500 \mathrm{cpm}$ per lane). Complexes were detected by autoradiography.

Formation and immunoprecipitation of ${ }^{125} I-t-P A / P A I-1$ complexes in serum. Whole-blood serum $(30 \mu \mathrm{l})$ was incubated with ${ }^{125} \mathrm{I}-\mathrm{t}-\mathrm{PA}\left(10^{4}\right.$ cpm) for $0-60 \mathrm{~min}$ at $37^{\circ} \mathrm{C}$. The reaction was rapidly terminated by the addition of either SDS sample buffer or the synthetic serine protease inhibitor $p$-amidinophenyl-methylsulfonyl fluoride (pAPMSF; $10 \mathrm{mM}$ final concentration). Samples treated with SDS sample buffer were analyzed without further treatment by SDS-PAGE and autoradiography, while samples treated with pAPMSF were immunoprecipitated according to the procedures described by Erickson et al. (16) Briefly, either antiserum against PAI-1 $(40 \mu \mathrm{l})$ or nonimmune serum $(40 \mu \mathrm{l})$ was added to protein A-coated Sepharose CL-4B beads ( $80 \mu \mathrm{g}$; Pharmacia, Uppsala, Sweden) that had been rehydrated and washed according to the manufacturer's instructions. ${ }^{125}$ I-t-PA-treated serum samples were added to the beads, diluted into buffer, and then incubated at $37^{\circ} \mathrm{C}$ for $1 \mathrm{~h}$ in a total volume of $250 \mu \mathrm{l}$. The beads were removed by centrifugation, the supernatant fluid was collected, and the beads were washed three times by centrifugation with $1 \mathrm{ml}$ of phosphate-buffered saline (PBS). Proteins bound to the beads were extracted by incubation with an equal volume of SDS-sample buffer. The resulting immunosupernatant fluids and/or the extracts from the immunoprecipitates were analyzed by SDS-PAGE followed by autoradiography.

Immunoradiometric assays (IRMA). To assess t-PA antigen, samples were diluted in IRMA buffer (PBS, 3\% BSA, 5 mM EDTA, 0.1\% Tween 80 , and $0.02 \% \mathrm{NaN}_{3}$ ) and incubated for $1.5 \mathrm{~h}$ at $37^{\circ} \mathrm{C}$ in microtiter wells precoated with goat anti-t-PA (50 $\mu$ l per well, 10 $\mu \mathrm{g} / \mathrm{ml})$. Plates were blocked with $3 \%$ BSA and washed three times after each step with PBS containing $0.1 \% \mathrm{BSA}, 0.05 \% \mathrm{NaN}_{3}$, and $0.05 \%$ Tween 80 . Bound t-PA was quantitated radiometrically after incubation with rabbit anti-t-PA, followed by ${ }^{125}$ I-labeled goat anti-rabbit IgG ( $10^{5} \mathrm{cpm}$ per well) (13). PAI-1 activity was quantitated by a t-PA binding assay (17). Briefly, samples and standard curves of purified PAI were prepared in IRMA buffer and incubated for $1 \mathrm{~h}$ at $37^{\circ} \mathrm{C}$ in microtiter wells precoated with purified t-PA $(50 \mu \mathrm{l}$ per well, $1 \mu \mathrm{g} / \mathrm{ml}$, overnight at $4^{\circ} \mathrm{C}$ ). Plates were blocked and washed three times following each step as described above. PAI bound to t-PA-coated wells was detected radiometrically after incubation $\left(1.5 \mathrm{~h}, 37^{\circ} \mathrm{C}\right)$ with rabbit antiserum to PAI-1 (1:75 dilution, $50 \mu \mathrm{l}$ per well) followed by ${ }^{125} \mathrm{I}$-labeled goat anti-rabbit IgG $\left(2.5-5 \times 10^{4} \mathrm{cpm}\right.$ per well; $1.5 \mathrm{~h}$ at $\left.37^{\circ} \mathrm{C}\right)$. PAI-1 antigen was quantitated by a two-site IRMA: purified monoclonal antibody (2D2) against human PAI-1 $(5 \mu \mathrm{g} / \mathrm{ml})$ in PBS was coated onto microtiter wells $\left(4^{\circ} \mathrm{C}\right.$ for $\left.16 \mathrm{~h}\right)$. After incubation with $3 \%$ BSA and washing, samples diluted in IRMA buffer were incubated in the antibody-coated wells at $37^{\circ} \mathrm{C}$ for $1.5 \mathrm{~h}$. Bound PAI-1 was quantitated by incubation with rabbit anti-PAI-1 antibody followed by ${ }^{125}$ I-labeled goat anti-rabbit IgG. In some experiments, serum samples were first mixed with purified PAI-1 $(100 \mu \mathrm{l}$ of $3.25 \mathrm{U} / \mathrm{ml})$ and incubated at $37^{\circ} \mathrm{C}$ for $15 \mathrm{~min}$ before assay for PAI-1 activity. Circulating t-PAPAI-1 complexes were assayed in a two-site IRMA using goat anti-t- 
PA as the immunoabsorbent and rabbit anti-PAI-1 as the detecting antibody (3).

Immunoblotting. Immunoblotting for PAI-1 antigen was performed as described (14). Samples were first subjected to SDS-PAGE. Proteins were then electrophoretically transferred to nitrocellulose using a buffer containing $50 \mathrm{mM}$ Tris base, $95 \mathrm{mM}$ glycine, $20 \%$ methanol, and $0.01 \%$ SDS. The nitrocellulose sheets were soaked in PBS containing $1 \%$ casein for $1 \mathrm{~h}$ at $23^{\circ} \mathrm{C}$ to block additional protein binding sites and were then incubated overnight at $4^{\circ} \mathrm{C}$ in $1 \%$ casein containing rabbit anti-PAI-1 (1:500 dilution). The nitrocellulose was washed three times and then incubated for $2 \mathrm{~h}$ at $23^{\circ} \mathrm{C}$ with ${ }^{125} \mathrm{I}$-labeled goat anti-rabbit IgG $\left(2 \times 10^{5} \mathrm{cpm} / \mathrm{ml}\right)$. After washing, the nitrocellulose sheets were dried and exposed to XAR x-ray film (Eastman Kodak Co., Rochester, NY) at $-70^{\circ} \mathrm{C}$.

\section{Results}

Enhanced in vivo fibrinolysis has been associated with excess release of endothelial plasminogen activator (t-PA) $(18,19)$. Patient serum was assayed on three separate occasions by IRMA for t-PA antigen. Patient t-PA antigen levels were within normal range (Table I). To determine if excessive fibrinolysis was mediated by deficient PAI activity, we examined the ability of inhibitors in the patient's blood to form SDSstable complexes with ${ }^{125}$ I-labeled t-PA. In this analysis, patient or control whole blood was incubated with radiolabeled t-PA for $0-24 \mathrm{~h}$ at $37^{\circ} \mathrm{C}$ followed by centrifugation, separation of plasma t-PA-inhibitor complexes on SDS polyacrylamide gels and autoradiography (Fig. 1). The three bands at the top of the gel are complexes of t-PA with $\alpha_{2}$-macroglobulin. The band in the middle of the gel represents $\alpha_{2}$-antiplasmin complexes. The upper band of the doublet is an unidentified protein which also binds t-PA. The lower bands in the gel are free ${ }^{125}$ I-labeled t-PA. The formation of ${ }^{125} \mathrm{I}-\mathrm{t}$-PA inhibitor complexes in both the patient and control blood are basically identical except for the lower band of the doublet at 92,000 D which is missing in the patient's samples (arrow). The absence of this ${ }^{125} \mathrm{I}$-t-PA-inhibitor complex band at early time points (i.e., $0.25 \mathrm{~h}$ ) suggested that the patient's bleeding diathesis may be caused by abnormally low levels of a fast-acting PAI.

The presence of low amounts of the ${ }^{125} \mathrm{I}-\mathrm{t}-\mathrm{PA}$-fast-acting inhibitor complex in control plasma is consistent with the observation that normal plasma contains quite low levels of fastacting PAI activity, whereas normal serum and platelets usually exhibit high levels of this inhibitor $(6,19)$. To analyze in further detail the activity of the patient's fast-acting PAI, we incubated ${ }^{125} \mathrm{I}-\mathrm{t}-\mathrm{PA}$ for short periods of time in serum prepared from the patient and from normal donors. Fig. $2 A$ indicates that the addition of ${ }^{125}$ I-t-PA to normal human serum results in the rapid formation of a 92,000-D band. In comparison, less

Table I. Serum t-PA and PAI-1 Concentrations

\begin{tabular}{lcc}
\hline & Patient & Controls \\
\hline t-PA antigen $(\mathrm{ng} / \mathrm{ml})$ & $4.7 \pm 0.9^{*}$ & $3.5-7.2$ \\
PAI-1 antigen $(\mathrm{ng} / \mathrm{ml})$ & $31.8 \pm 5.4$ & $19.6-42.2$ \\
PAI-1 activity $(\mathrm{U} / \mathrm{ml})$ & $0.36 \pm 0.12$ & $0.87-1.81$ \\
\hline
\end{tabular}

Patient and five concurrently obtained control samples were assayed for t-PA and PAI-1 by IRMA.

* Data represent mean \pm SD of determination from three to five separate sets of experiments.

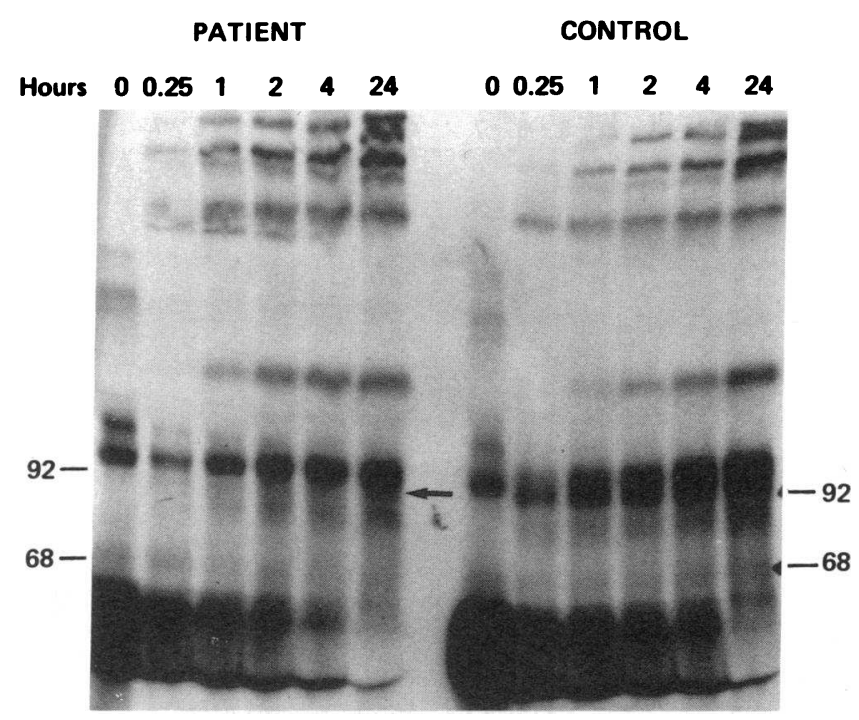

Figure 1. Blood proteinase inhibitor complex assay. Freshly drawn citrated whole blood was incubated with radioiodinated t-PA for 0-24 $\mathrm{h}$, and then centrifuged and the plasma was analyzed by SDSPAGE (4-10\% polyacrylamide gradient) and autoradiography. All bands on the patient's gel are identical to control except for the lower band of the doublet (arrow) which is missing from patient's blood. Molecular mass markers given in kilodaltons.

${ }^{125} \mathrm{I}$-t-PA-inhibitor complex $(92,000 \mathrm{D})$ was formed when ${ }^{125} \mathrm{I}-$ t-PA was incubated in serum prepared from the patient's blood (Fig. $2 \mathrm{~B}$ ). Thus, the majority of ${ }^{125} \mathrm{I}$-t-PA added to the patient's serum was found to migrate in parallel with free ${ }^{125} \mathrm{I}$ t-PA (Fig. $2 A$, lane 1 ) even after 0.5-1-h incubations (e.g., Fig. $2 B$, lanes 6 and 7 ), whereas the amount of free ${ }^{125}$ I-t-PA was markedly reduced after a $15-\mathrm{min}$ incubation with control serum (i.e., Fig. $2 A$, lane 5).

Immunoprecipitation experiments were performed to demonstrate that this ${ }^{125} \mathrm{I}-\mathrm{t}-\mathrm{PA}$-inhibitor band was composed of ${ }^{125} \mathrm{I}-\mathrm{t}-\mathrm{PA}$ bound to PAI-1 (Fig. 3). For this purpose, ${ }^{125} \mathrm{I}-\mathrm{t}-\mathrm{PA}$ was again incubated $\left(30 \mathrm{~min}, 37^{\circ} \mathrm{C}\right)$ with both control and patient serum, the reaction was terminated by the addition of pAPMSF and the samples were immunoprecipitated with either rabbit anti-PAI-1 or nonimmune serum. Supernatants of ${ }^{125}$ I-t-PA-treated patient serum (lane 1) or control serum (lane 3) immunoprecipitated with nonimmune serum contained both free ${ }^{125}$ I-t-PA and a 92,000-D ${ }^{125}$ I-t-PA-inhibitor complex, whereas supernatants of samples immunoprecipitated with anti-PAI- 1 serum contained only free t-PA (lanes 2 and 4, respectively). As described above, the patient samples contained fewer ${ }^{125}$ I-t-PA-inhibitor complexes than the controls. Elution of the protein A-Sepharose bead immunoprecipitates with SDS-sample buffer revealed a small amount of free ${ }^{125} \mathrm{I}-\mathrm{t}-$ PA using both nonimmune and anti-PAI-1 serum. However, a 92,000-D band also was eluted from the patient and control samples immunoprecipated with rabbit anti-PAI-1 (lanes 7 and 9 , respectively). Less ${ }^{125}$ I-t-PA-inhibitor complex was recovered from the patient immunoprecipitate than from control. These data suggest deficient complex formation between patient PAI-1 and ${ }^{125} \mathrm{I}-\mathrm{t}-\mathrm{PA}$.

To quantitate deficient patient PAI-1 activity, a number of additional immunologic assays were performed. When patient PAI-1 functional activity was assessed in an independent immunoradiometric t-PA binding assay, it was found to be mark- 
A

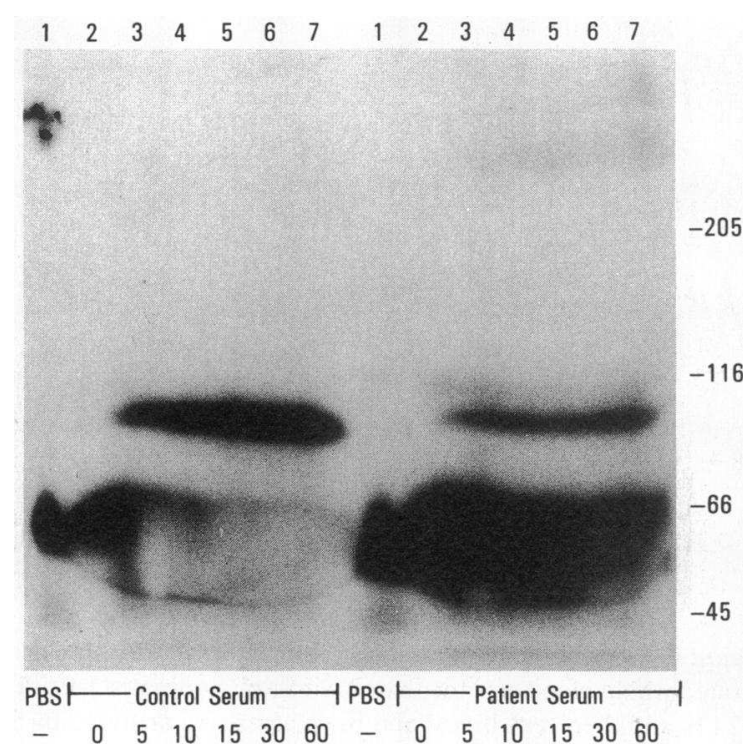

Figure 2. Analysis of normal serum and patient serum for fast-acting PAI activity. Whole blood serum was prepared from blood collected from either a normal human donor $(A)$ or the patient $(B) .{ }^{125} \mathrm{I}-\mathrm{t}-\mathrm{PA}$ in PBS (lane $1 ; 10^{4} \mathrm{cpm}$ ) was incubated at $37^{\circ} \mathrm{C}$ in the respective serum samples $(30 \mu \mathrm{l})$ for the indicated times (lane 2, 0 min; lane 3, $5 \mathrm{~min}$; lane 4, $10 \mathrm{~min}$; lane $5,15 \mathrm{~min}$, lane $6,30 \mathrm{~min}$; lane 7,60 min). Samples were subjected to SDS-PAGE on a $4-10 \%$ polyacrylamide gradient following by autoradiography. Positions of molecular mass standards in kilodaltons are indicated.

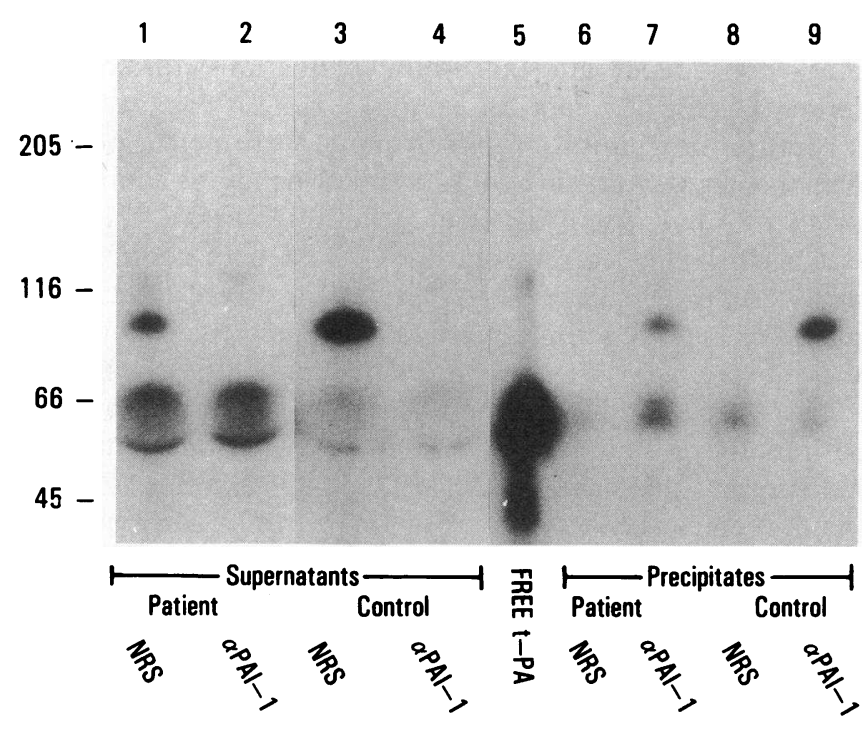

Figure 3. Immunoprecipitation of ${ }^{125} \mathrm{I}$-treated control serum and patient serum with antibodies to PAI. ${ }^{125} \mathrm{I}-\mathrm{t}-\mathrm{PA}\left(10^{4} \mathrm{cpm}\right)$ was incubated in either patient serum (lanes $1,2,6,7$ ) or control serum (lanes $3,4,8,9$ ) for $30 \mathrm{~min}$ at $37^{\circ} \mathrm{C}$. The reaction was terminated by the addition of pAPMSF ( $10 \mathrm{mM}$, final concentration) and immunoprecipitated with either nonimmune rabbit serum (NRS; lanes 1,3 , 6,8 ) or antiserum against PAI-1 (lanes $2,4,7,9$ ) as described in Methods. The resulting immunosupernatant fluids (lanes 1-4) or extracts from the immunoprecipitates (lanes 6-9) were analyzed by SDS-PAGE (4-10\% gradient) followed by autoradiography. Lane 5 represents free t-PA. Positions of molecular mass markers in kilodaltons are indicated. edly reduced $(0.36 \pm 0.12 \mathrm{U} / \mathrm{ml})$ compared to control donors $(0.87-1.81 \mathrm{U} / \mathrm{ml} ; n=5)$ (Table I). Thus by both IRMA and by immunoprecipitation experiments, patient PAI-1 demonstrates diminished functional activity as evidenced by an inability to form normal complexes with t-PA. This decreased activity was found in both serum and plasma, as well as in platelet-rich plasma and platelet lysates $(0.01 \mathrm{U} / \mathrm{ml} \mathrm{PAI-1}$ activity in patient platelet lysates vs. $0.09-0.11 \mathrm{U} / \mathrm{ml}$ in control lysates, $n=2$ ). However, PAI-1 antigen levels were found to be within the normal range in serum (Table I) and in platelet lysates. Patient circulating t-PA-PAI- 1 complexes were modestly reduced $(1.9 \mathrm{ng} / \mathrm{ml} \mathrm{vs}$. $2.5-5.3 \mathrm{ng} / \mathrm{ml}$ in control plasma; $n$ $=2$ ).

A number of proteases (e.g., thrombin, activated protein C, elastase) (6) could potentially have reduced patient PAI-1 activity either via complex formation with PAI-1 or by direct cleavage of the inhibitor. We assessed these possibilities initially by Western blot analysis of patient serum and plasma. As mentioned above, little PAI-1 antigen is present in control platelet-poor plasma under normal conditions (Fig. $4 A$, lanes $2,4,8$, and 10). In contrast, PAI-1 in serum from four normal donors (Fig. $4 A$, lanes 3, 5, 9, and 11), as well as PAI-1 in patient serum (lane 7), was detected primarily at the molecular mass of $46,000 \mathrm{D}$. Unfortunately, the large amount of albumin present in plasma and serum samples distorts the electrophoretic mobility of PAI- $1(50,000 \mathrm{D})$ to a slightly lower molecular mass (6), thus potentially interfering with one's ability to distinguish between the native form and a proteolytically cleaved form of PAI-1 in this system. To accurately examine the molecular characteristics of the patient's PAI-1, we also analyzed patient and control platelet lysates for PAI-1 by immunoblotting. Fig. $4 \mathrm{~B}$ indicates that the patient's platelet-derived PAI-1 migrated as a single band $(50,000 \mathrm{D}$; lane 6$)$ in parallel with the PAI-1 present in control platelets (lane 1 ). A high- $M_{\mathrm{r}}$ immunoreactive band could be detected by this technique if t-PA was incubated with the platelet lysates prior to electrophoresis (lanes 2 and 7). Furthermore, cleavage of PAI-1 was also observed following a 10-min incubation of control or patient platelet lysates with either thrombin (lanes 3 and 8 ) or elastase (lanes 4 and 9), respectively. Thus, no evidence is provided by Western blot to indicate that patient PAI-1 had either been cleaved or had complexed with a protease.

Circulating antibodies against plasma PAI-1 could explain the patient's decreased serum PAI-1 functional activity. This possibility was addressed in three separate sets of experiments. Purified PAI-1 was incubated for $15 \mathrm{~min}$ at $37^{\circ} \mathrm{C}$ with an equivalent volume of either buffer, patient, or control serum and then assayed for PAI- 1 activity in the immunoradiometric t-PA binding assay (Table II). Control serum containing normal endogenous PAI-1 produced the expected augmentation in PAI-1 activity. Patient serum had little demonstrable effect on the activity of purified PAI-1, thus demonstrating again minimal patient PAI-1 serum activity and providing no evidence for an inhibitor to PAI-1 in patient serum. Similarly, patient serum had no inhibitory effect on PAI-1 activity when incubated with control serum before activity determinations. In separate experiments, a direct assay for the presence of antibodies to PAI-1 was performed. Purified PAI-1 was bound to microtiter plates, then incubated with patient plasma followed by radiolabeled goat anti-human IgG. Utilizing this assay, no antibodies to PAI-1 were detected in patient plasma (data not shown). 
A

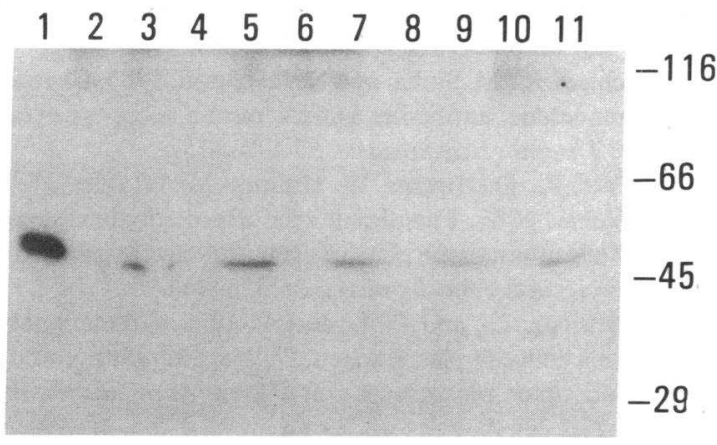

B

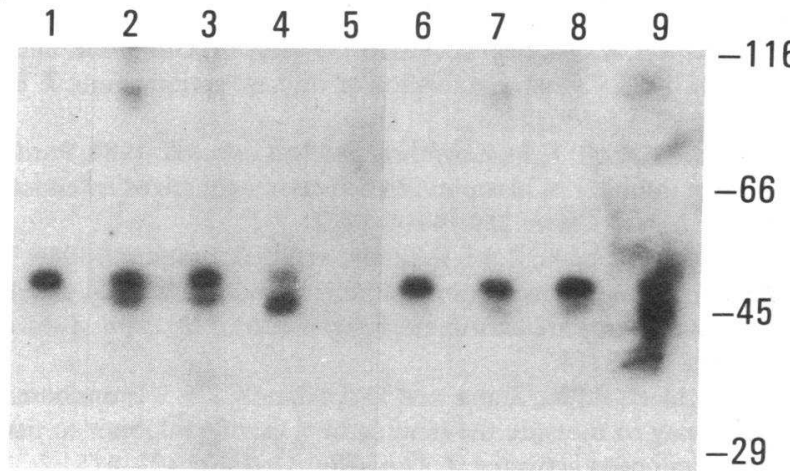

Figure 4. Western blot for PAI-1 antigen in plasma, serum, and platelets. $(A)$ Purified PAI-1 (lane $1 ; 5 \mathrm{ng}$ ) and $8 \mu \mathrm{l}$ of various blood samples (platelet-poor plasma-lanes 2, 4, 6, 8, and 10; whole blood serum-lanes $3,5,7,9$, and 11 ) were fractionated on a $10 \%$ SDSpolyacrylamide gel and electrophoretically transferred to nitrocellulose. PAI-1 antigen was detected by incubation with rabbit anti-PAI1 followed by incubation with ${ }^{125}$ I-labeled goat anti-rabbit IgG as described in Methods. Patient samples are in lanes 6 and 7, while control samples from four different normal donors are in lanes 2 and 3,4 and 5,8 and 9 , and 10 and 11 , respectively. Under normal conditions, little PAI-1 antigen is detected in control platelet-poor plasma. (B) Control platelets (lanes $1-4 ; 40 \mu \mathrm{l}$ per lane) or patient platelets (lanes 6-9; $40 \mu \mathrm{l}$ per lane) were lysed with Triton X-100 and incubated $\left(10 \mathrm{~min}, 37^{\circ} \mathrm{C}\right)$ in the absence or presence of various proteases: lanes 1 and 6, PBS alone; lanes 2 and 7, 10 ng t-PA; lanes 3 and $8,10 \mathrm{U}$ thrombin; lanes 4 and $9,1 \mu \mathrm{g}$ elastase. Lane 5 contained a mixture of t-PA, thrombin, and elastase in the absence of platelet lysates. Samples were subjected to SDS-PAGE and immunoblotted for PAI-1 antigen. Positions of molecular mass markers in kilodaltons are indicated.

\section{Discussion}

Disordered fibrinolysis has infrequently been associated with a bleeding diathesis. Homozygous $\alpha_{2}$-antiplasmin deficiency causes a severe hemorrhagic diathesis and is associated with almost no plasma antiplasmin functional activity and little detectable $\alpha_{2}$-antiplasmin antigen $(20,21)$. Our patient's $\alpha_{2}$ antiplasmin antigen and activity levels ranged from $52 \%$ to $65 \%$. Patients with heterozygous $\alpha_{2}$-antiplasmin deficiency infrequently have a history of excessive bleeding and, in contrast to our patient, have normal serum levels of plasminogen (20-22). Lifelong bleeding disorders have also rarely been associated with persistent evidence of hyperfibrinolysis and excess circulating levels of t-PA $(17,18)$. Our patient had normal circulating levels of t-PA antigen, measured on three separate
Table II. Effect of Patient Serum on Activity of Purified and Blood-derived PAI-1

\begin{tabular}{lc}
\hline \multicolumn{1}{c}{ Sample } & PAI-1 activity \\
\hline & U/ml \\
PAI-1 $(5 \mathrm{ng})+$ buffer* $^{*}$ & $1.07 \pm 0.13^{\ddagger}$ \\
PAI-1 $(5 \mathrm{ng})+$ control serum & $2.12 \pm 0.23$ \\
PAI-1 $(5 \mathrm{ng})+$ patient serum & $1.15 \pm 0.10$ \\
Buffer + control serum & \\
Patient serum + control serum & $1.01 \pm 0.17$ \\
Patient serum + buffer & $0.95 \pm 0.20$ \\
\end{tabular}

* Purified PAI-1 was incubated with $100 \mu$ l of either buffer or serum for $15 \mathrm{~min}$ at $37^{\circ} \mathrm{C}$ before IRMA for PAI-1 activity.

${ }^{\ddagger}$ Data represent means \pm SD from triplicate determinations.

${ }^{\S}$ Serum and/or buffer samples $(100 \mu \mathrm{l})$ were mixed and incubated at $37^{\circ} \mathrm{C}$ for 15 min before IRMA for PAI-1 activity.

occasions, normal levels of urokinase antigen, and did not have an increase in circulating levels of t-PA-PAI-1 complexes. Additionally, excess release of plasminogen activators would not be expected to deplete functional PAI-1 compartmentalized in platelets, nor would a primary excess release of t-PA be likely to explain low platelet PAI-1 activity coupled with normal platelet PAI-1 antigen by immunoblotting analysis.

Low PAI-1 activity, confirmed by two independent methods of assay, in combination with normal levels of t-PA and PAI-1 antigen, suggests a qualitative defect in PAI-1. The explanation for the decreased functional activity of this patient's PAI-1 is unclear. PAI-1 interacts not only with plasminogen activators but also with a wide variety of other proteolytic enzymes $(1,2,4)$. It is thus possible that excessive protease activity in the patient's blood might have inactivated PAI-1, before assay, by either proteolytic cleavage or by the formation of inactive protease-PAI- 1 complexes. Immunoblotting analysis (Fig. 4) of plasma and serum, as well as analysis of platelet-derived PAI-1, was particularly helpful in eliminating this possibility since it indicated that both patient and control PAI-1 migrated similarly on SDS-PAGE.

Another potential explanation for decreased blood PAI-1 activity is the presence of circulating inhibitors to PAI-1. Francis et al. (23), in a preliminary report, have described a patient with amyloidosis, accelerated fibrinolysis, and a bleeding diathesis. This patient had normal t-PA antigen levels but PAI-1 activity was undetectable owing to the presence of neutralizing antibodies to PAI-1. The patient also had depressed levels of both plasminogen and $\alpha_{2}$-antiplasmin and, like our patient, responded to the therapeutic administration of EACA. Functional and immunologic assays coupled with the use of purified PAI-1 failed to demonstrate an anti-PAI-1 inhibitor in our patient's serum or plasma.

Our data suggest that diminished PAI-1 activity in this patient is most probably associated with an abnormality in the PAI-1 molecule itself. Further experiments will be required to determine the exact defect in PAI-1. An abnormality in the patient PAI- 1 molecule could be due to alternative processing of PAI-1 mRNA or to a defect in the 12.2-kb PAI-1 gene located on the long arm of chromosome $7(6,24)$.

Elevated levels of serum PAI-1 have been associated with a 
postulated hypofibrinolytic state and with an increased risk for thrombosis $(25,26)$, suggesting that PAI-1 may play an important role in mediating vascular fibrinolysis. Most t-PA in blood is complexed to PAI-1. Since t-PA antigen levels in our patient were normal, these data suggest that the decrease in PAI-1 activity disrupts the normal fibrinolytic balance in plasma, resulting in a relative increase in free t-PA and accelerated fibrinolysis. The successful treatment of our patient's hemorrhagic episode with EACA, an antifibrinolytic agent which blocks t-PA, plasminogen, and plasmin binding to fibrin substrate, supports this conclusion (27). The evidence for persistent accelerated fibrinolysis in our patient (moderate comsumption of both $\alpha_{2}$-antiplasmin and plasminogen, as well as a shortened euglobulin lysis time) suggests that ongoing production of functionally active PAI-1 is necessary to complex with small amounts of continuously released free plasminogen activator. In a similar manner, recent data suggests that activated procoagulants such as factor $\mathrm{Xa}$ and $\mathrm{Va}$ are continuously formed within the vascular system and are opposed by natural anticoagulant mechanisms (28).

We conclude that our patient's bleeding diathesis was most likely due to hyperfibrinolysis and deficient PAI-1 activity. The data suggest that decreased PAI-1 activity results in an increase in free t-PA, which in turn causes spontaneous plasmin generation and predisposes to excessive bleeding. To our knowledge, the evidence presented provides the first demonstration of a link between decreased PAI-1 activity and disordered hemostasis, and supports a role for PAI-1 in the control of in vivo fibrinolysis.

\section{Acknowledgments}

We thank Janet Scrimger for the preparation of the manuscript.

This work was supported by National Institutes of Health grants HL-40376 (to Dr. Schleef) and HL-35774 (to Dr. Levitt). Dr. Levitt is the recipient of a Research Career Development Award (K04 HL-02213-01) from the National Institutes of Health. This work was performed in part in Dr. D. J. Loskutoffs laboratory and was supported in part by grants HL-22289 and HL-16411.

\section{References}

1. Dano, K., P. Andreasen, J. Grondahl-Hansen, P. Kristensen, L. Nielsen, and L. Skriver. 1985. Plasminogen activators, tissue degradation and cancer. Adv. Cancer Res. 44:139-266.

2. Reich, E. 1978. Activation of plasminogen: a general mechanism for producing localized extracellular proteolysis. In Molecular Basis of Biological Degradative Proteases. R. Berlin, H. Herrman, I. Lepov, and J. Tanzer, editors. Academic Press, Inc., Orlando, FL. 155-169.

3. Erickson, L., R. Schleef, T. Ny, and D. Loskutoff. 1985. The fibrinolytic system of the vascular wall. Clin. Haematol. 14:513-530.

4. Francis, C., and V. Marder. 1986. Concepts of clot lysis. Annu. Rev. Med. 37:187-204.

5. Sprengers, E., and C. Kluft. 1987. Plasminogen activator inhibitors. Blood. 69:381-387.

6. Loskutoff, D., M. Sawdey, and J. Mimuro. 1988. Type 1 plasminogen activator inhibitor. Prog. Hemostasis Thromb. 9:87-115.

7. Rheinwald, J., J. Jorgensen, W. Hahn, A. Terpstra, T. O'Connell, and K. Plummer. 1987. Mesosecrin: a secreted glycoprotein produced in abundance by human mesothelial, endothelial and kidney epithelial cells in culture. J. Cell Biol. 104:263-275.

8. Collucci, M., J. Paramo, and D. Collen. 1986. Inhibition of one-chain and two-chain forms of human tissue-type plasminogen activator by the fast-acting inhibitor of plasminogen activator in vitro and in vivo. J. Lab. Clin. Med. 108:53-59.
9. Sakata, Y., D. Loskutoff, C. Gladson, C. Hekman, and J. Griffin. 1986. Mechanism of protein C-dependent clot lysis: role of plasminogen activator inhibitor. Blood 68:1218-1223.

10. Schleef, R., M. Sinha, and D. Loskutoff. 1985. Characterization of two monoclonal antibodies against human tissue-type plasminogen activator. Thromb. Haemostasis. 53:170-175.

11. Tate, K., D. Higgins, W. Holmes, M. Winkler, H. Heyneker, and G. Vehar. 1987. Functional role of proteolytic cleavage at arginine-275 of human tissue plasminogen activator as assessed by site-directed mutagenesis. Biochemistry. 26:338-343.

12. Hekman, C., and D. Loskutoff. 1988. Kinetic analysis of the interactions between plasminogen activator inhibitor 1 and both urokinase and tissue plasminogen activator. Arch. Biochem. Biophys. 262:199-210.

13. Bevilacqua, M., R. Schleef, M. Gimbrone, and D. Loskutoff. 1986. Regulation of the fibrinolytic system of cultured human vascular endothelium by interleukin 1. J. Clin. Invest. 78:587-591.

14. Schleef, R., M. Bevilacqua, M. Sawdey, M. Gimbrone, and D. Loskutoff. 1988. Cytokine activation of vascular endothelium. J. Biol. Chem. 263:5797-5803.

15. van Mourik, J., D. Lawrence, and D. Loskutoff. 1984. Purification of an inhibitor of plasminogen activator synthesized by endothelial cells. J. Biol. Chem. 259:14914-14921.

16. Erickson, L. A., C. M. Hekman, and D. J. Loskutoff. 1985. The primary plasminogen-activator inhibitors in endothelial cells, platelets, serum, and plasma are immunologically related. Proc. Natl. Acad. Sci. USA. 82:8710-8714.

17. Schleef, R., M. Sinha, and D. Loskutoff. 1985. Immunoradiometric assay to measure the binding of a specific inhibitor to tissuetype plasminogen activator. J. Lab. Clin. Med. 106:408-415.

18. Aznar, J., A. Estelles, V. Vila, E. Reganon, F. Espana, and P. Villa. 1984. Inherited fibrinolytic disorder due to an enhanced plasminogen activator level. Thromb. Haemostasis. 52:196-200.

19. Booth, N., B. Bennett, G. Wijngaards, and J. Grieve. 1983. A new life-long hemorrhagic disorder due to excess plasminogen activator. Blood. 61:267-275.

20. Aoki, N., H. Saito, T. Kamiya, K. Koie, Y. Sakata, and M. Kobakura. 1979. Congenital deficiency of $\alpha_{2}$-plasmin inhibitor associated with severe hemorrhagic tendency. J. Clin. Invest. 63:877-884.

21. Miles, L., E. Plow, K. Donnelly, C. Hougie, and J. Griffin. 1982. A bleeding disorder due to deficiency of $\alpha_{2}$-antiplasmin. Blood. 59:1246-1251.

22. Kluft, C., E. Vellenga, E. Brommer, and G. Wijngaards. 1982. A familial hemorrhagic diathesis in a Dutch family: an inherited deficiency of $\alpha_{2}$-antiplasmin. Blood. 59:1 169-1180.

23. Francis, R., H. Liebman, S. Koehler, and D. Feinstein. 1986. Accelerated fibrinolysis in amyloidosis: specific binding of tissue plasminogen activator inhibitor by an amyloidogenic monoclonal IgG. Blood. 68:333a. (Abstr.)

24. Ginsburg, D., R. Zeheb, A. Yang, U. Rafferty, P. Andreasen, L. Neilsen, K. Dano, R. Lebo, and T. Gelehrter. 1986. cDNA cloning of human plasmingen activator inhibitor from endothelial cells. J. Clin. Invest. 78:1673-1680.

25. Hamsten, A., B. Wiman, U. de Faire, and M. Blomback. 1985. Increased levels of a rapid inhibitor of tissue plasminogen activator in young survivors of myocardial infarction. N. Engl. J. Med. 313:15571563.

26. Nilsson, I., H. Ljungher, and L. Tengborn. 1985. Two different mechanisms in patients with venous thrombosis and defective fibrinolysis; low concentration of plasminogen activator or increased concentration of plasminogen activator inhibitor. Br. Med. J. 290:1453-1456.

27. Marder, V., F. Butler, and G. Barlow. 1987. Antifibrinolytic therapy. In Hemostasis and Thrombosis. R. Colman, J. Hirsh, V. Marder, and E. Salzman, editors. J. B. Lippincott Co., Philadelphia. 380-394.

28. Bauer, K., and R. Rosenberg. 1987. The pathophysiology of the prethrombotic state in humans: insights gained from studies using markers of hemostatic system activation. Blood. 70:343-350. 